\title{
Poeta en Nueva York: Lorca's Soledad confusa
}

\begin{abstract}
Poeta en Nueva York purports to be Federico Garcia Lorca's poetic response to the destructive underbelly of modernity with its rampant and dehumanized Capitalism. But the collection's emphasis on solitudehighlighted in the titles of two of the sections - also recalls Góngora's best known poem Soledades, one of the foremost examples of the pastoral genre in the Spanish language. Góngora had been a major influence in Lorca's poetics before his trip to New York and to mark Góngora's tricentenary he had even tried and failed to write a continuation or third 'Soledad'. The Golden Age poet had become a source of influence and anxiety for Lorca and his New York poetry represents his attempt to overcome it, subverting the pastoral framework of his forebear. This paper will consider how the conflict of pastoral and anti-pastoral elements inform and shape Lorca's poems in this collection.
\end{abstract}

Oye mi doble voz de remo y canto FGL, 'Soledad insegura'

New York, where Lorca stayed for almost nine months from June 1929, was the poet's first experience of living abroad. According to his public declarations he found the rampant capitalist ethos and the impersonality of the American metropolis alienating and dehumanizing and the social inequality and racial discrimination appalling. ${ }^{1}$ But, as recorded in his letters home, he was also captivated by the magnitude of the cityscape, by the vibrant music scene of the Harlem Renaissance, by avant-garde experiments in theatre, dance and cinema, and, presumably, if not explicitly acknowledged, by the expansiveness and visibility of its gay scene. The chiasmic parallelism used by Lorca in his presentation of the collection: 'He dicho "un poeta en Nueva York", y he debido decir "Nueva York en un poeta"', also suggests a reciprocity between subject and object.

The literary and cinematic versions that shaped Lorca's vision of the modern city have been well documented. Among them the dystopian mechanical world in Fritz Lang's expressionist film Metropolis which was first reviewed by Buñuel in La Gaceta Literaria in May 1, 1927 and then screened in Cine club Español in 1928. Also influential was Le Corbusier's The City of Tomorrow, a critique of New York that surveys the problems of modern urban life and proposes some alternative solutions. Lorca had met Le

\footnotetext{
${ }^{1}$ See his lecture on 'Un poeta en Nueva York', in FGL: Obras completas, ed. by Miguel García Posada, 4 vols (Barcelona, Galaxia Gutenberg/ Círculo de Lectores: 1996), III, 163-73.
} 
Corbusier when the architect was invited to give a talk at the Residencia in 1928, and as Terence McMullan argues in a lucid comparative study, some of his ideas about urban planning and modern architecture can be detected in Lorca's New York poems, while also taking some distance from the Le Corbusieur's neo-Cubist aesthetics. ${ }^{2}$ While in America, Lorca may have had the opportunity to see the avant-garde documentary film Manhatta (1921), whose aerial views of the city, with shots of the crowds under the skyscrapers among columns of smoke and steam, and architectural landmarks such as Wall St and Brooklyn Bridge, interspersed with intertitles from Walt Whitman's poetry, have a striking similarity with some of the scenarios of Lorca's New York collection. ${ }^{3}$ Moreover, according to Ángel de Río, the newly appointed Spanish lecturer at Columbia University who became one of his hosts in New York, among Lorca's reading in America were some contemporary novels. ${ }^{4}$ One was the Spanish translation of John Dos Passos's Manhattan Transfer, a critique of American capitalism of the 1920s in which the city becomes an urban jungle whose ethos of survival of the fittest crushes the individual, and the other, All Quiet on the Western Front by the German novelist Eric Remarque, a denunciation of the conditions endured by soldiers in the First World War that describes its devastating effects on the troops, in this case the Germans. ${ }^{5}$ Del Río's list includes T.S. Eliot The Waste Land which Lorca would have read in the still unpublished Spanish version by the Puerto Rican writer Ángel Flores. Later on, during the public reading in Madrid of his New York poems, Lorca mentioned T.S. Eliot in connection with the urban crowds. Both poets saw the jungle in the metropolis and described the urban experience as alienating and disturbing, and some textual similarities do indeed suggest that the reading of Tierra baldía, the title of the Spanish version, may have influenced Lorca's own writing. ${ }^{6}$ Lorca's depersonalized multitudes find a parallel in Eliot's Dantean image of the crowd that flows over London Bridge, likewise Lorca's image of the Hudson getting drunk on oil ('el Hudson se emborracha con aceite') resonates with London's oily Thames in The Waste Land ('the river sweats / oil and tar'). Del Río remarks on the 'almost

\footnotetext{
2 Terence McMullan 'Federico García Lorca's Poeta en Nueva York and The City of Tomorrow', Bulletin of Hispanic Studies, LXXIII (1996), 65-79.

${ }^{3}$ Manhatta (1921) by Charles Sheeler and Paul Strand, see America's Cool Modernism: O'Keeffe to Hopper (exhibition catalogue), (Oxford: Ashmolean Museum, 2018), pp. 160.

${ }^{4}$ Ángel del Río, 'Introduction: Poet in New York: Twenty-Five Years Later', Federico García Lorca: Poet in New York, translated by Ben Belitt (London: Thames and Hudson, 1955), ix-xxxix (p. xxx)

${ }^{5}$ For these influences see Lloyd Halliburton 'All Quiet in the Western Front: Remarque's Contribution to Lorca's Poeta en Nueva York' Neohelicon XXVII.2 (2000), 123-31; and 'Manhattan Transfer: The Clandestine Influence on Lorca's Poeta en Nueva York' Anales de la Literatura Española, 9 (1993), 79-84; see also Andrés Morales Minhic 'Metropolis de Fritz Lang y Poeta en Nueva York de Federico García Lorca', Revista de Literatura Chilena, 53 (1998), 137-44.

${ }^{6}$ Tierra baldía was published in Barcelona (Cervantes 1930); Howard Young traces some lexical similarities between the two in 'Sombras fluviales: PNY y The Waste Land', Boletín de la Fundación García Lorca, 4.10 (1992), 165-77.
} 
exact verbal analogy' between Lorca's line': ‘¿Qué voy a hacer? ¿Ordenar los paisajes?’ in the poem 'Nueva York: Oficina y denuncia 'and Eliot's: 'What shall I do now? What shall I do now? [...] Shall I at least set my lands in order?'. ${ }^{7}$ Certainly the coincidence is intriguing even if the phrase in Spanish does not carry the idiomatic meaning of the English. But Lorca's image had preceded his encounter with Eliot's poetry. The same phrase had appeared in his lecture of 1926 'La imagen poética de D. Luis de Góngora' applied to the latter's poetry: '[Góngora] ordena sus paisajes analizando sus componentes' an image that encapsulates the idea of the poet alienated from nature. ${ }^{8}$

Yet Góngora is rarely mentioned in connection with Poeta en Nueva York. Commentators have taken their cue from Lorca's own words in the often quoted interview with Ernesto Giménez Caballero in December 1928: 'Vuelta a la inspiración. Inspiración, puro instinto, razón única del poeta. La poesía lógica me es insoportable. Ya está bien la lección de Góngora', ${ }^{9}$ and also from the references in the lecture delivered in New York in 1930 where Góngora is demoted to the lesser realm of poetic imagination, superseded by the kind of visionary inspiration associated with St Juan de la Cruz. ${ }^{10}$

By then the growing influence of the Catalan avant-garde and of Surrealism in Lorca's idearium informs his valuation of the irrational and unconscious over the rationality and aesthetic consciousness identified with Góngora's poetry. ${ }^{11}$ Dámaso Alonso describes this change in very Lorquian term as a return 'hacia la raíz subterránea de la inspiración poética'. ${ }^{12}$ In assessing Lorca's declaration we need to take into account that despite the popularity achieved by Romancero gitano, the poet was soon to dissociate himself from its Gongorine aesthetics after the negative reception of the collection among his

\footnotetext{
${ }^{7}$ Del Río p. xxxi. McMullan (1996) sees in these lines Lorca's dissociation from Le Corbusier's architectural philosophy based on order and geometry redolent of Cubist aesthetics, and by extension from the 'poesía pura' or the dehumanized art championed by Ortega y Gasset - an aesthetics Lorca had espoused in the mid-1920s. (p.76)

${ }^{8}$ FGL: OC, III, 53-77 (p, 66); the lecture on Góngora was first delivered in February 1926 at the Granada Atheneum and repeated a year later in Madrid at the Residencia de Estudiantes, as part of the programme of events for the tricentenary of Góngora's death, see 'nota textual' in Christopher Maurer (ed), FGL: Conferencias, 2 vols (Madrid Alianza:1984) I, pp. 87-89.

9 'Itinerarios jóvenes de España: FGL', FGL: Obras Completas, III, 364-67 (p. 366).

10 'Góngora es el perfecto imaginativo, el equilibrio verbal, y el dibujo concreto. No tiene misterio ni conoce el insomnio. En cambio San Juan de la Cruz es lo contrario, vuelo y anhelo, afán de perspectiva y amor desatado. Góngora es el académico, el terrible profesor de lengua y poesía', in 'Tres modos de poesía' (delivered in New York in February 1930), FGL: OC III, 107-09 (p. 108); on this lecture see Andrew A. Anderson, 'Lorca at the Crossroads: 'Imaginación. Inspiración. Evasión' and the 'novísimas estéticas', Anales de la Literatura Española Contemporánea, XVI (1991), 149-73.

${ }^{11}$ See Andrew A. Anderson, 'García Lorca's Poemas en prosa and Poeta en Nueva York: Dalí, Gasch, Surrealism and the Avant-Garde', in A Companion to Spanish Surrealism, ed. Robert Havard (London: Tamesis, 2004), $163-82$.

12 'Góngora y la poesía contemporánea', Estudios y ensayos gongorinos (Madrid: Gredos, 1955), 532-79 (p. 769) Alonso wrote the essay in 1927 but revised it before its publication in 1932.
} 
circle of avant-garde friends in the Residencia, in particular Dalí and Buñuel who made their views clear to him shortly after its publication in July 1928. While in New York Lorca revised his lecture on Góngora along the new lines and he read the new version in Cuba in the Spring of 1930. As Christopher Maurer points out, the changes were not extensive but significant, reflecting a less enthusiastic appreciation of Góngora's poetics, which in the latter version are relegated from the sublime to the accomplished. ${ }^{13}$

From this vantage point, it is rather baffling that Lorca should decide in 1932 to publish the earlier version of the Góngora lecture, with an added disclaimer: 'se trata de una conferencia de vulgarización para un público más o menos alejado de estas cuestiones literarias y que no responde exactamente al criterio actual del conferenciante sobre cuestiones gongorinas.' ${ }^{14}$ Yet, whatever Lorca's view might have been at the time, his esteem for Góngora's achievements was soon to be restored to its former prominence, if we are to judge that by the declaration he made only a year later:

Paul Valéry tiene imaginación, una imaginación extraordinaria. Inspiración, no. Es tan difícil unir los dos Milagros - el de dentro, el de fuera - en un milagro solo... Paradigma inmortal de este triunfo es don Luis de Góngora (OC III, p. 418).

Perhaps unsurprisingly, from the mid-thirties, some Gongorine resonances resurface in Lorca's poetry, as in Llanto por Ignacio Sánchez Mejías and his Sonetos del amor oscuro - one of the latter with the phrase 'soneto gongorino' in the title. These fluctuations indicate that Lorca's relation to Góngora was far more than a passing infatuation. Instead, my contention here is that Lorca's movement away from Góngora was one of gradual internalization, and Poeta en Nueva York was a pivotal point in this process.

lan Gibson has noted that in the Góngora lecture 'the impression is that Lorca is really glossing his own work', ${ }^{15}$ therein establishing what has been described as a mirroring relation in which Góngora becomes 'la imagen refleja e inversa de Lorca'. ${ }^{16}$ The ambivalence implicit in this relationship would come to the fore in Poeta en Nueva York where Lorca's struggle for poetic individuation becomes a pressing concern. Despite Dámaso Alonso's view that 'influencias de Góngora sobre Lorca, si llegan a

\footnotetext{
${ }^{13}$ See Christopher Maurer's introduction in FGL: Conferencias, I, pp. 15-30.

14 'La imagen poética de Don Luis de Góngora', Residencia III-4 (Madrid, oct 1932); Maurer includes this version in the 'Apéndice' of FGL: Conferencias, II, 127-54.

15 Ian Gibson, Federico García Lorca: A Life (London: Faber \& Faber, 1989), p.159.

${ }^{16}$ Nadine Ly, 'Lorca y la teoría de la escritura: 'La imagen poética de don Luis de Góngora', La valoración actual de la obra de García Lorca: actas del coloquio celebrado en la Casa de Velázquez (Madrid: Universidad Complutense/ Casa de Velázquez, 1988), 163-79 (p. 169).
} 
existir, son difíciles de fijar ${ }^{\prime}{ }^{17}$ some parallels in imagery have been traced back to Lorca's first book of poems, and even if those may be attributed to their common Andalusian heritage, Góngora's imprint is undeniable in Romancero gitano and has been amply documented. ${ }^{18}$ The influence was already acknowledged among his contemporaries. ${ }^{19}$ Illustrative is Gerardo Diego's jinojepa - 'Romance apócrifo de D. Luis a caballo' - published under Lorca's name in the issue of La Gaceta Literaria dedicated to Góngora's tricentenary, which was written in the manner of Lorca's ballads intermingled with parodic allusions to Góngora's Soledades. The result, according to Diego, was a success: 'Mi broma de la Gaceta Literaria - justo castigo a tu incalificable deserción del homenaje a 'don Luis' - surtió el efecto apetecido. Picaron muchos'. ${ }^{20}$

As Diego's quip highlights, Lorca's participation in the events organized for the tricentenary, contrary to expectations, was lukewarm. In December 1927, after his lecture in Madrid, he joined in the group of poets who went to Seville, responding to Ignacio Sánchez Mejías's invitation, but he had not attended the official acts in the spring, and only after much insistence on the part of his friends did he eventually submit one poem to the issue dedicated to Góngora of the Málaga-based magazine Litoral. $^{21}$ It was the enigmatic ballad 'Muerto de amor' which was later included with some variations in his Romancero gitano. His original plan had been to submit his own 'Soledad' on which he had been at work as early as March 1926, but the project was never completed. The publication in the same issue of Litoral of Rafael Alberti's 'Soledad tercera', a long 132-line silva divided in 15 sections, must have been vexing for Lorca after his failed attempt. ${ }^{22}$

He had first mentioned his intentions to Guillén in a letter full of enthusiasm which included a short sample of four hendecasyllabics:

Palabras de cristal y brisa oscura redondas sí, los peces mudos hablan.

\footnotetext{
${ }^{17}$ Estudios y ensayos gongorinos (1955), quoted by Jack de Groot, Intertextuality through Obscurity: The Poetry of Federico Garcia Lorca and Luis de Góngora (New Orleans: The University Press of the South, 2002), p. 153.

${ }^{18}$ See Christopher Maurer in A Companion to FGL, edited by Federico Bonaddio (London and New York: Tamesis, 2007), pp. 28-29.

${ }^{19}$ See Dennis Perri 'Reviews (1928-290) of the Romancero gitano: Competing Readings', Anales de la Literatura Española Contemporánea 14. 1-3 (1989), 97-114 (notes 17, 21).

${ }^{20}$ Mario Hernández 'Gerardo Diego y FGL: Correspondencia inédita y poemas', Boletín de la Fundación FGL, 2 (1987), 11-38 (p. 21).

${ }^{21}$ Litoral 5-6-7 (October 1927); excerpts from his lecture on Góngora were published in Verso y Prosa with the title 'En torno a Góngora' in 1927.

${ }^{22}$ Lorca's endeavour is recorded in his correspondence with Jorge Guillén, Federico en persona: Semblanza y epistolario (Buenos Aires: Emecé editors, 1959), pp. 83-8, 122-25, 128-29 [FGL: OC, III: pp 883-87, 949-52]
} 
Academia, en el claustro de los iris bajo el éxtasis denso y penetrable.

Later, in 1927, the same lines reappear within a longer fragment in a letter also addressed to Guillén. This time the tone was hesitant, the added title 'Soledad insegura' expressing self-doubt about his ability to complete the poem and revealing his inhibitions in relation to Góngora:

Dime que te parecen estos versos. Y dímelo pronto. Trabajo mucho y creo que quizá no consiga terminar esta Soledad. Por otra parte, me parece una irreverencia el que yo me ponga a hacer este homenaje. No sé. ${ }^{23}$

Lorca was clearly struggling to separate his own voice from Góngora's and anxious to assert his own poetic identity. As he tells Guillén: ‘Esto es un fragmento [...] Si te parece puedo mandar otra cosa más mía. INo creas! Lo digo en el sentido de que sea más flexible.' (p. 123). That the first fragment that figures in Guillén's letter is interrupted at the point where the pilgrim is about to speak, is in itself an expression of the poet's anxiety of influence: ${ }^{24}$

Mientras en medio del horror oscuro mintiendo canto y esperando miedo voz inquieta de naufrago sonaba:

While in New York the memory of his 'Soledad insegura' could not have been far from Lorca's mind. He coincided with two inveterate Gongoristas among his friends: Dámaso Alonso and Ignacio Sánchez Mejías. ${ }^{25}$ Discussion about Góngora must surely have taken place between them. While Mejías only arrived in the last few weeks of Lorca's stay in New York, Alonso, who was a visiting lecturer at

\footnotetext{
${ }^{23}$ FGL: OC, I, pp. 482-484. For a detailed analysis of Lorca's 'Soledad insegura' see Javier Pérez Bazo 'Las 'Soledades' gongorinas de Rafael Alberti y FGL o la imitación ejemplar', Criticón 74 (1988), 125-54 (pp. 142-51); see also de Groot (2002), pp. 173-89; 'Romance apócrifo de Don Luis a caballo' appeared in La Gaceta Literaria in June 1927.

${ }^{24}$ The three fragments included in the letter to Guillén are out of sequence; for the full reconstructed poem see Javier Pérez Bazo (1988), pp. 145-46. Here and elsewhere in this essay I use the term influence in the sense given by Harold Bloom as a metaphor that 'implicates a matrix of relationships - imagistic, temporal, spiritual, psychological - all of them ultimately defensive in their nature', The Anxiety of Influence: A Theory of Poetry, $2^{\text {nd }}$ edn. (New York and Oxford: OUP, 1997), p. xxiii. Bloom's Freudian interpretation of poetic history, where the notion of anxiety of influence describes the struggle for pre-eminence by poets with their precursors, is illuminating for the concerns explored in this essay.

${ }^{25}$ The bullfighter and playwright Sánchez Mejías had been the sponsor of the trip to Seville of a group of poets, among them Alonso and Lorca, as part of the Góngora tricentenary celebrations. In Rafael Alberti's recollection of 1942 '[Sánchez Mejías] se lanzó con arrojo en nuestra guerra gongorina, aficionándose a las Soledades, llenando su memoria de los más difíciles y ceñidos arabescos de don Luis', La arboleda perdida (Barcelona: Bruguera, 1982), p. 224 [ quoted by Andres Soria Olmedo in iViva don Luis! 1927: desde Góngora a Sevilla (Madrid: Residencia de Estudiantes, 1997), p. 26].
} 
Hunter College from September 1929, overlapped with him for over six months. After the publication in 1927 of his edition of the Soledades accompanied with his prose version, Alonso had become an established Góngora scholar. That same year he had been awarded the Premio de Literatura Nacional for an essay on the modernity of Góngora's poetry, and the Golden Age poet was also the subject of his doctoral thesis. Alonso had been one of the instigators and a keen participant of the events of the tricentenary in the Spring of 1927 and was also among the cohort who travelled to Seville later that year. While in New York he gave a lecture in Columbia University, where Lorca was enrolled, on 'Góngora: una nueva perspectiva en la literatura de España' ${ }^{26}$ and he might have contributed to Lorca's revised lecture. Alonso, however, remained unconvinced of Lorca's approach to Góngora, which he deemed more passionate and intuitive than knowledgeable, as he would remark later on: 'Lo que no sabe lo inventa [...] Federico no se para en barras y da de algunos fragmentos de las Soledades una interpretación en absoluto alejada de lo evidente'. ${ }^{27}$

In the preamble to his edition of Soledades Alonso had referred to the claims made by Góngora's contemporaries Pellicer and Diez de Rivas about the poet's alleged original plan to write four Soledades. According to Diez de Rivas the two outstanding were the 'Soledad de las selvas' (third Solitude) and 'Soledad del yermo' (fourth Solitude). Alonso had quoted appreciatively from Alberti's 'Soledad tercera' in the essay awarded the Premio Nacional de Literatura, where he also disclosed Lorca's intention to write a continuation of the Soledades, a detail that he did not correct in the revised version of the essay published in $1932 .{ }^{28}$ He might have been aware of the existence of 'Soledad insegura', even though the text was only made public when Guillén published the letters in $1959 .{ }^{29}$ Or perhaps he thought it was still a work in progress. In any case, even though Alonso was, according to Ángel del Río, one of Lorca's 'constant companions' in New York, he never referred to the poetry written by Lorca in this period. His preference was for the more 'neo-popular' strain in Lorca's work, as he was to declare in his essay of 1937 'FGL y la expresión de lo español' ${ }^{30}$ Coincidentally, Alonso's arrival in the

\footnotetext{
${ }^{26}$ Hispania 12 (1929), p. 612.

27 Dámaso Alonso, Poetas españoles contemporáneos (Madrid: Gredos, 1952), p. 276.

28 'Los dos [Alberti and Lorca] han demostrado su devoción a Góngora intentando cada uno una continuación de las Soledades','Góngora y la poesía contemporánea', in Dámaso Alonso, Estudios y ensayos gongorinos (Madrid: Gredos, 1955) 532-79 (p. 573); In a letter to Jose Maria Cossio of 23 ${ }^{\text {rd }}$ January 1927 Gerardo Diego writes: 'Alberti está escribiendo una tercera soledad, la de 'las selvas' según el plan de D. Luis, de la que me leyó un largo y laberíntico fragmento', quoted in iViva don Luis! 1927 (1997), p. 101.

${ }^{29}$ Jorge Guillén, Federico en persona: Semblanza y epistolario (Buenos Aires: Emecé editors, 1959).

30 In Poetas españoles contemporáneos (Madrid: Gredos, 1952), 271-80 [first published in 1937 in Homenaje al poeta FGL; in 1944 in Ensayos sobre la poesía Española].
} 
States was preceded by the publication of the English translation of a ballad Lorca had dedicated to him - 'Preciosa y el aire' - in the New York magazine Alhambra edited by Ángel Flores, the translator of The Waste Land. ${ }^{31}$

Poeta en Nueva York has been interpreted in a very personal register as Lorca's response to his emotional circumstances and his experience of the modern metropolis, but as I will argue here it can also be read as the realization of his long awaited modern sequel to Góngora's Soledades, specifically the third Soledad or Solitude of the Jungle. The concept of the urban jungle had gained currency since the publication of Upton Sinclair's best-selling novel, The Jungle in 1906, a denunciation of the American meat industry set in the abattoirs of Chicago, which was made into a silent film in 1914. Sinclair's disturbing descriptions of the slaughterhouse are strongly reminiscent of Lorca's poem 'Nueva York: oficina y denuncia'. ${ }^{32}$ In any case, the association between the city and the jungle is also integral to Lorca's vision of New York. The word 'selva' appears several times in the collection, together with an abundant imagery of tropical fauna including iguanas, crocodiles, monkeys, caimans, hippopotamus, snakes and lions. Also, among the graphic material Lorca had selected to illustrate the poems, there is one depicting some African masks and a photo-collage of a cityscape with superimposed images of snakes and lizards.

Lorca had been announcing the publication of Poeta en Nueva York from 1930, but he only set out to work on the structure of the book some five years later. ${ }^{33}$ At that point he must have arranged the poems in ten sections with individual headings, two of them containing the word 'soledad': the first one opens the collection: 'I. Poemas de la soledad en Columbia University', and the other is preceded by the phrase that Lorca had considered for a while as the title of the whole collection: 'VI. Introducción a la muerte - Poemas de la soledad en Vermont'. ${ }^{34}$ The prominence given by Lorca to the word 'Soledad' can be seen as a token of recognition to Góngora, and further scrutiny of the collection reveals the

\footnotetext{
31 'Ballad of Preciosa and the Wind' translated by Daniel Solana, Alhambra 1, 3 (New York: August 1929).

32 'They brought about ten thousand head of cattle every-day, and as many hogs, and half as many sheep - which meant some eight or ten million live creatures turned into food every year [...] - a very river of death', Upton Sinclair, The Jungle (New York: Crosset and Dunlap, 1906), p. 38; Sinclair, a novelist and investigative journalist, had been a graduate student at Columbia University, and he was also the author of the chronicle No pasarán! The Battle of Madrid (1937). The Spanish translation of The Jungle, Los envenenadores de Chicago, appeared in 1908. ${ }^{33}$ Andrew A. Anderson offers a detailed description of the original manuscript in the first annotated edition of the complete collection, FGL: Poeta en Nueva York (Madrid: Galaxia Gutenberg, 2013); Nigel Dennis provides a history of the textual and editorial difficulties up to the reappearance of the original manuscript in Vida y Milagros de un manuscrito de Lorca: en pos de Poeta en Nueva York (Santander: Sociedad Menéndez Pelayo, 2000).

${ }^{34}$ Andrew A. Anderson's 2013 edition includes the facsimile of these two pages.
} 
extent of his imprint. Some of Góngora's favoured syntactic patters have been identified in Lorca's 'Panorama ciego de Nueva York. ${ }^{35}$ Common motifs such as the use of mythological references as well as specific topoi as in the lament of the bereaved father for his dead son, or the contemplation of ruins, can apply to the larger poetic tradition but there are scattered images which have an inescapable Gongorine ring to them, such as the 'alba mentida de New York', or the combination 'sierpe de cristal' (426). The latter is echoed in the opening poem of the collection 'Vuelta de paseo' ('Entre las formas que van hacia la sierpe / y las formas que buscan el cristal'), and is revisited in 'Nocturno del hueco' ('y eran duro cristal definitiva / las formas que buscaban el giro de la sierpe'). ${ }^{36}$ It is worth noting that the phrase, split in the former instance, reaches a synthesis in the second while still keeping the two words separated in different lines. The same impulse can be discovered in Lorca's engagement with Góngora's material which reveals a dialectical engagement with what can be considered his precursor, an act of simultaneous acknowledgement and distancing which suggests a ritual of separation. Likewise within a Bloomian framework, Edward H. Friedman has interpreted Góngora's reworking of pastoral as a way to unburden his work of the pressure exerted by his poetic predecessors, mainly Garcilaso. ${ }^{37}$ The lineage is noted by Lorca who quotes from Garcilaso's Eglogas in the epigraph of the IV section: 'Poemas del Lago Eden Mills' ('Nuestro ganado pace, el viento espira').

The title Poeta en New York already suggests a relation between the human and the environment and the literary mode that has traditionally explored this relationship is the pastoral. In its overall design the collection is built on the same premises of Soledades, presenting a modern version of its dominant theme and, by extension, of pastoral in general: the conflict of values identified by two different settings, the natural and the urban environment respectively. In particular a reworking of the Renaissance topos of 'menosprecio de corte y alabanza de aldea'. ${ }^{38}$ In contrast to the pastoral landscape encountered by the shipwrecked pilgrim in Soledades, Lorca's urban stroller finds himself stranded in the 'moderno artificio' of the city. However, the two settings are not as antithetical as may appear

\footnotetext{
35 See Derek Harris, García Lorca: Poeta en Nueva York (London: Grant and Cutler, 1978), p. 21; Clementa Millan's edition (Madrid: Cátedra, 1988), pp. 95-7, describes the model as 'si no A, B' and 'No A, B', p. 96.

${ }^{36}$ cf Góngora's line 'en roscas de cristal serpiente breve' ('Oda a la toma de Larache') and 'sierpe de cirstal' ('Soledad I').

${ }^{37}$ Edward H. Friedman 'Creative Space: Ideologies of Discourse in Garcilaso's Polifemo', in Cultural Authority in Golden Age Spain, edited by Marina Scordilis Brownlier and H.U. Gumbrecht (The Johns Hopkins UP, 1995), pp. 5178.

${ }^{38}$ Luis Fernández Cifuentes's insight 'creo que gobierna el conjunto arquitectónico de Poeta en Nueva York una nueva, irónica, acaso perversa versión del topos pastoral' is not elaborated, in 'Lorca en Nueva York: arquitecturas para un poeta', Boletín de la Fundación Federico García Lorca, IV. 10 (febrero 1992), 125-35 (p. 132).
} 
because in both artifice and nature interpenetrate each other. ${ }^{39}$ While in the landscape of Soledades we find 'agricultura urbana', we are presented with urban nature in images such as that of 'enjambres de ventanas' or 'el paisaje de las escaleras' in New York. Moreover, within New York's urban dystopia the poet finds an imaginary pastoral community in the dispossessed and marginalized who are excluded from the modern capitalist ethos of the city. The apparent innocence and simplicity of goatherds and fishermen is replicated in the communities of blacks and homosexuals, specifically those among them attached to the instinctual life, whose figurehead Lorca saw in the American poet Walt Whitman, and those who had not been corrupted by greed and self-interest. This vision proves to be as removed from reality as the mythic shepherds that feature in the works of the pastoral canon. ${ }^{40}$ We even find a pastoral retreat in the farmer's cabin of the countryside near Shandaken in the Catskill Mountains of New York State, which Lorca visited during the Summer and which became the setting of the section $\mathrm{V}$ 'En la cabaña del Farmer', flanked by 'Poemas del Lago Eden Mills' and 'Introduccion a la muerte (Poemas de la soledad en Vermont)'. If the pastoral is described as an 'escape from adult experience to childhood innocence', ${ }^{41}$ this is the temporal axis in $P N Y$ shuttling from a nostalgically recalled past, a time identified with nature, now irretrievably lost, to an unsettling present where the correspondence between natural and human orders has been lost and where death is all pervasive.

Whereas the taciturn pilgrim of Góngora's Soledades has been transformed into a more outspoken persona in Lorca's New York, both are figures of exiles, both victims of the indifference of their beloved ones. ${ }^{42}$ Furthermore, Lorca's view of the Soledades as a succession of lyric set pieces bound together through the device of the pilgrim, is not far from the critical view that sees PNY as a set of poems, loosely arranged, following the biographical pattern of the poet's experience in America. ${ }^{43}$ In both cases, self-reflexivity is an important dimension to their work.

\footnotetext{
${ }^{39}$ Marsha S. Collins offers a resumé of critical views on Góngora's treatment of the relationship between nature and art in Soledades: Góngora's masque of the Imagination (Columbia, Missouri: University of Missouri Press, 2002), pp. 122-24.

40 The disparities can in turn be interpreted as reflecting Lorca's own conflicted attitudes toward racial difference, homosexuality and modernity, as suggested by P.J. Smith's discussion of the social and artistic circles that Lorca must have encountered, 'New York, New York: Lorca's Double Vision', Tesserae: Journal of Iberian and Latin American Studies, 6.2 (2000), 169-180.

${ }^{41}$ Roger Sales, English Literature in History 1780-1830: Pastoral and Politics (London: Hutchinson, 1983) p. 15.

${ }^{42}$ A recent description of Góngora's pilgrim can equally apply to Lorca's poet: 'He is a knowing and intertextually indeterminate pilgrim (novelistic, non-epic, lyric, sentimental, secular), wandering in wonderment through a multicursal maze of a defamiliarized generic schemata', Isabel Torres, 'Broaching the void: Reconsidering Góngora's Indeterminate Poetics', BSS, XC (2013), 107-29 (p. 108).

${ }^{43}$ John Beverly describes Góngora's Soledades as 'a story passing through a succession of moments of experience'in Aspects of Góngora's Soledades (John Benjamins Publishing, 1980), p. 87.
} 
Poeta en Nueva York represents a turning point in Lorca's poetic idiom, moving beyond the 'neo-popularist' aesthetics of his previous collections, particularly his Romancero gitano, to avant-garde experimentalism. ${ }^{44} \mathrm{~A}$ transition which brings to mind the change of style in Góngora's poetics, from the more popular romances and letrillas, to the obscure and intricate style of his more baroque work which gained him the sobriquet of 'principe de las tinieblas'. One of the features of Lorca's collection is the obscurity of its imagery, and the critical response is reminiscent of that elicited by Soledades, illustrated in Richard Predmore's remark: 'many passages in many poems are abstruse in the extreme'. ${ }^{45}$ Góngora's 'cambio repentino' mentioned by Lorca in his lecture where he also describes it as a 'revolución lírica' (96-7), is generally identified with the year 1610, when the poet returned to Córdoba and produced the 'Oda a la toma de Larache' introducing his new 'culterano' style and paving the way for his longer and more complex poems: Fábula de Polifemo y Galatea and the Soledades. It is tempting to see a hidden allusion to this turning point in the date 1910 which appears in the title of one of Lorca's poems '1910 Intermedio', and also figured in another 'Tu infancia en Menton' whose previous title was 'Ribera 1910.' Incidentally, the difference of three hundred years between the two dates conjures up the emblematic occasion of Góngora's tricentenary, which marked the epiphany of the hitherto neglected Golden Age poet into the Spanish literary canon. We can also see in the inversion of the digits $9 / 6$ a figure for the chiasmus, one of the rhetorical devices used repeatedly by Góngora, which can also be applied to the simultaneously complementary and antithetical relation between Poeta en Nueva York and Soledades. The ritual of separation is enacted in Lorca's insistence on negative constructions throughout the collection, from the 'destructive adjectivisation' noted by Derek Harris, ${ }^{46}$ illustrated in titles such as 'Panorama ciego', or 'Iglesia abandonada', to the iteration of negative sentences and terms. The urgency expressed through these recurring negative constructions suggests an underlying adversarial impulse and the pervasive imagery of phantasmagoria throughout the collection conveys the sense of a submerged presence haunting the poet. I will explore this presence in 'Vuelta de paseo', the opening poem of the collection which introduces its prevailing affect while conjuring up the image of Góngora.

In fact, 'Poemas de la Soledad en Columbia University', the initial section of Poeta en Nueva York, comprising four poems, can be read as an invocation of Góngora. It is framed by an allusion to the

\footnotetext{
${ }^{44}$ Maurer lists the various aspects of what he describes as Lorca's 'abrupt departure from the poetic manner of his earlier work', FGL Conferencias, I, p. xiii.

${ }^{45}$ Richard L. Predmore, Lorca's New York Poetry: Social Injustice, Dark Love, Lost Faith (Durham N C.: Duke University Press, 1980), p.x.

${ }^{46}$ Harris's critical guide (1978) provides several examples of the use of adjectives to negate the positive of a noun, pp. 15-16.
} 
myth of Icarus, an image of the over-reacher, whose figure has generally functioned in literary tradition as a representation of the lover and the poet. ${ }^{47}$ Góngora's Soledades contain frequent allusions and references to the myth. Its presence is most conspicuous in 'Soledad segunda' in a passage where the pilgrim compares his fate to that of Icarus, which has been interpreted as a symbol for the poet's aspirations: ${ }^{48}$
Audaz mi pensamiento
el Cenit escaló, plumas vestido, cuyo vuelo atrevido, si no ha dado su nombre a tus espumas, de sus vestidas plumas conservarán el desvanecimiento los anales diáfanos del viento. (137-43)

Whereas Góngora's image lingers on the 'vuelo atrevido', Lorca focuses on its aftermath portraying Icarus as a passive victim of fate, as suggested by the choice of verb in the opening poem of the collection: 'Asesinado por el cielo' and reinforced a few lines into the same poem with the image of a butterfly drowned in the inkwell, which introduces the collection's metapoetic concern. The allusion is picked up again in the last line of the section's concluding poem: 'y que el mar recordó İde pronto! / los nombres de todos sus ahogados'. Already the title of the first poem 'Vuelta de paseo' can be related to Góngora poetics, as in his lecture Lorca had used the image to refer to poetic inspiration: 'se vuelve de la inspiración como se vuelve de un país extranjero'. ${ }^{49}$ This in turn evokes the self-referential opening lines of Góngora's exordium to the Soledades, his dedication to the duque de Béjar:

Pasos de un peregrino son, errante, cuantos me dictó versos dulce Musa,

\footnotetext{
${ }^{47}$ In Ovid's account of the myth, Icarus's daring flight ends in self-destruction when, using the wax wings fashioned by his father Daedalus, he flies too close to the sun, plunging into the sea, subsequently named after him, and drowning. According to John H. Turner 'en la tradición de Garcilaso y Cetina, Icaro es la imagen del amante o artista', in 'Góngora y un mito clásico', NRFH 23 (1974), 88-100 (p. 95); In terms of precedence Góngora should be closer to the figure of the skilful craftsman Daedalus, the artificer of the labyrinth and of the wings father and son use to escape from it.

${ }^{48}$ For John Beverley 'el vuelo de Icaro [...] sería una alegoría del trabajo poético de Góngora, del 'vuelo peligroso' de sus invenciones linguísticas', Aspects of Góngora's Soledades, p. 127.

${ }^{49}$ Building on the correspondence between the Icarus figure in both Góngora's pilgrim and Lorca's poet in New York, Gabriela Leal Gonzalez contends that 'Poeta en Nueva York evoca la arquitectura de las Soledades', concluding that 'tal vez Lorca no se haya alejado tanto de Góngora como se supondría, in "Clínica y selva de la anatomía"...' el peregrino Poeta en Nueva York', cdigital.uv.mx (January 1998), 153-71 (p.160, note 23). Related to the concerns of this essay, see the unpublished doctoral dissertation by Martine Doyle Price, Confronting Death in Soledades and Poeta en Nueva York, Texas Tech University (May 2016); also Andrew A. Anderson 'Et in Arcadia Ego: Thematic Divergences and Convergences in Lorca's Poema doble del lago Eden', BHS, 74.4 (1997), 409-29.
} 
en soledad confusa,

perdidos unos, otros inspirados.

Here the poet introduces himself as the 'peregrino errante', just like the poetic persona in Poeta en Nueva York who expresses his desire to revert to the state of nature ('dejaré crecer mis cabellos') and is associated with the concept of Soledad. But in Lorca's vision, the order in nature has been radically disturbed and the unsettling imagery of the new environment describes a post-apocalyptic scenario. ${ }^{50}$ Con el árbol de muñones que no canta y el niño con el blanco rostro de huevo.

Con los animalitos de cabeza rota

y el agua harapienta de los pies secos.

Con todo lo que tiene cansancio sordomudo

y mariposa ahogada en el tintero.

Here, the anthropomorphic tree which is an emblem of nature in the pastoral world appears stunted and mute and if the child's face conjures up the traditional association of the pastoral with childhood, its description as white and egg-like conveys a sense of depersonalized opacity. The animal husbandry implied in the use of the diminutive 'animalitos' is negated here by the violent adjectival phrase 'de cabeza rota', and the flowing Arcadian water has become dirty and stagnant. The anaphoric couplets create an increasing tension ending with a gesture that embraces an irresponsive and exhausted nature ('todo lo que tiene cansancio sordomudo), ${ }^{51}$ negating the pathetic fallacy of pastoral convention, and ending in the image of an inkwell where a butterfly has drowned. The image of the poet as a butterfly fatally attracted to the light that will kill it also appears in Soledades, and is recalled in Lorca's lecture. The lamp here has been transformed into an inkwell suggesting a literary source of allure. This is followed by an image of the split self whose identity has become grafted on to the landscape ('Tropezando con mi rostro distinto cada día') The concluding exclamation reiterates Icarus's fate with more urgency. The repetition of the phrase enacts a circularity that is in itself a tacit acknowledgement of poetic influence while the use of exclamation marks accentuates the sense of burden and anxiety. But we can also detect a note of defiance in the end-stopped concluding line. The collection abounds with images of emptying out the self with references to bodily excretions: spit,

\footnotetext{
${ }^{50}$ The disparity in the tone of the poem and Lorca's letters of this period has been noted by critics. For a documented biographical study see Christopher Maurer and Andrew A. Anderson, Federico García Lorca en Nueva York y La Habana: cartas y recuerdos (Barcelona: Galaxia Gutenberg/ Círculo de Lectores, 2013).

${ }^{51} \mathrm{Cf}$. Dali's concept of 'helómetro para sordomudos' which appeared in the text 'San Sebastian' dedicated to Lorca, where it is explained as an instrument for measuring the Saint's agony, see Rafael Santos Torroella 'Los putrefactos' de Dalí y Lorca: Historia y antología de un libro que no pudo ser (Madrid: Publicaciones de la Residencia de Estudiantes, 1995), p. 57.
} 
blood, milk, tears, vomit and urine, as well as dislodgement conveyed in the repeated word 'hueco'. In both cases the implied desire is for a release, an opening up or 'desembocadura', spelled out in the line: 'Lo que importa es esto: hueco. Mundo solo. Desembocadura' ('Navidad en el Hudson', Nueva York 29 December 1929). Not surprisingly the poem concludes with an ambiguous disawoval:

¡Oh brisa mía de límites que no son míos!

¡Oh filo de mi amor! ¡Oh hiriente filo!

Harold Bloom uses the term Tessera to describe one of the strategies through which a poet engages agonistically with poetic tradition, elaborating upon the precursor's work in an antithetical manner, that is: maintaining the original's terms and ideas but in reverse. ${ }^{52} \mathrm{I}$ believe that something similar can be detected in Poeta en Nueva York with regard to Soledades.

When Lorca returned from the States, he declared that it had been the most useful experience of his life. For all his seeming dissatisfaction with the impersonality, materialism and artificiality of the city, the experience was also a stimulus and a source of renewal for the poet..$^{53}$ It allowed him to confront modernity first hand, introducing urban images and related vocabulary for the first time in his poems, and abandoning the regularity in line and form of his earlier poetry. New York's skyline and technological achievements together with the city's avant-garde theatrical productions may well have encouraged his involvement in radical formal experimentation. His interest in cinema also flourished; he wrote a film-script while in New York, and many poems in his collection assimilate cinematic techniques -most prominently the montage sequence - into poetic practice. He witnessed the Harlem Renaissance phenomenon with its vibrant musical scene - Harlem became one of his favourite haunts - and Lorca's sympathy with idioms derived from popular music combined with the receptivity of his poetic language to music help him incorporate the spirit of black music - jazz, blues, spirituals - into his poetry. Also, the early 1920s was the golden era for black female blues singers such as Ida Cox and Bessie Smith, and perhaps it is no coincidence that strong complex female characters enter his own theatrical works after visiting America. The contact with the socially marginalized African American community might have had an impact too in the way he projected his work, and on his return to Spain he became more socially engaged establishing a travelling theatre company to disseminate classical drama in rural Spain. Finally, he came up against the expansiveness and visibility of the New York gay scene before the Depression which might have influenced his attitude to homosexuality, more openly treated in his subsequent

\footnotetext{
${ }^{52}$ Harold Bloom, 'Tessera or Completion and Antithesis'. The Anxiety of Influence: A Theory of Poetry (2 ${ }^{\text {nd }}$ edn., New York and Oxford: OUP, 1997), pp. 49-73.

${ }^{53}$ In Lorca's own words: 'Había recibido la experiencia mas útil de mi vida', FGL: OC, III, p. 173.
} 
work. $^{54}$ Last, but certainly not least, the experience allowed him to cast himself as a poet in New York. ${ }^{55}$ Poetic expression and the role of the poet in the world of modernity is a preoccupation felt throughout the collection. In one of the poems Lorca mentions New York's imperfect anxiety ('la angustia imperfecta de Nueva York'), ${ }^{56}$ and perhaps one of the lessons Lorca took from the metropolis was the possibility of a poetry wrought from ugliness and imperfection. Above all, however, in New York he was able to confront his precursor in a quest to undo his influence. This intra-poetic relationship is inscribed in the antithetical pastoral of Lorca's collection. ${ }^{57}$ Like the courtier of the Pastoral tradition Lorca returned from New York a changed poet.

Cxderos.2018

\footnotetext{
${ }^{54}$ Drawing on George Chauncey's historical survey of gay life in New York (1994), Paul Julian Smith claims that in the 1920 s 'gay sociality was surprisingly integrated into general spaces, visible and accessible to all', 'New York, New York: Lorca's Double Vision', Tesserae: Journal of Iberian and Latin American Studies, 6.2 (2000), p.172.

${ }^{55} \mathrm{Cf}$. Lorca's statement to his friends on his return from the US: 'He hecho lo mas difícil: he sido poeta en Nueva York', quoted in A.A. Anderson (1997), p. 409.

${ }^{56} \mathrm{Cf}$. Wallace Stevens's lines in 'The Poems of our Climate' (1938) on the modern poet: 'The imperfect is our paradise. / [....] delight.../ lies in flawed words and stubborn sounds'.

${ }^{57}$ On the topic of Lorca's poetic self-consciousness, Federico Bonaddio has argued that 'to become a poet is to enter the world of poets, to become subject of the desires that cohabit there, though not always comfortably: the desires for creativity, for self-integrity and authenticity, for recognition and affiliation, for originality and selfdifferentiation', Federico García Lorca: The Poetics of Self-Consciousness' (London: Tamesis/ Boydell and Brewer, 2010), p. 14.
} 